\title{
Correction to: Decent Work and Work Engagement: A Profile Study with Academic Personnel
}

\section{Marta Graça ${ }^{1} \cdot$ Leonor Pais $^{1}$ (10 - Lisete Mónico ${ }^{1}$ (1) Nuno Rebelo Dos Santos ${ }^{2}$ (D) - Tânia Ferraro ${ }^{1,3}$ (D) $\cdot$ Rita Berger ${ }^{4}$}

Published online: 20 January 2020

(C) The International Society for Quality-of-Life Studies (ISQOLS) and Springer Nature B.V. 2020

\section{Correction to: Applied Research in Quality of Life https://doi.org/10.1007/s11482-019-09780-7}

In the article Decent Work and Work Engagement: A Profile Study with Academic Personnel (https://doi.org/10.1007/s11482-019-09780-7) written by Graça, Pais, Mónico, dos Santos, Ferraro, \& Berger, in Table 1, the likert'"options-of-response of dimensions 'Dedication' and 'Absorption' begin at ' 0 ' (zero) not 1 . Unfortunately, it appears as 1 in the first version of publication. All the Likert'option-of-response in this instrument (the UWES) variate among ' 0 '” (zero) and '6' (six).

The original article has been corrected.

The online version of the original article can be found at https://doi.org/10.1007/s11482-019-09780-7

Tânia Ferraro

taniaferraro@gmail.com

Extended author information available on the last page of the article 
Publisher's Note Springer Nature remains neutral with regard to jurisdictional claims in published maps and institutional affiliations.

\title{
Affiliations
}

\section{Marta Graça ${ }^{1} \cdot$ Leonor Pais $^{1} \cdot$ Lisete Mónico $^{1} \cdot$ Nuno Rebelo Dos Santos $^{2} \cdot$ Tânia} Ferraro $^{1,3} \cdot$ Rita Berger ${ }^{4}$

\author{
Marta Graça \\ martamgraca@gmail.com \\ Leonor Pais \\ leonorpais@fpce.uc.pt \\ Lisete Mónico \\ lisete.monico@ fpce.uc.pt \\ Nuno Rebelo Dos Santos \\ nrs@uevora.pt
}

Rita Berger

ritaberger@ub.edu

1 Faculty of Psychology and Educational Sciences (FPCE), University of Coimbra, Rua do Colégio Novo, S/N, 3000-115 Coimbra, Portugal

2 Departamento de Psicologia, Escola de Ciências Sociais, Universidade de Évora, Largo dos Colegiais, 2, 7004-516 Évora, Portugal

3 Departamento de Psicologia e Educação, Universidade Portucalense (UPT), Rua Dr. António Bernardino de Almeida, 541, 4200-072 Porto, Portugal

4 Department of Social Psychology and Quantitative Psychology, Faculty of Psychology, University of Barcelona, Passeig Vall d'Hebron, 171, E-08035 Barcelona, Spain 